DOI https://doi.org/10.24144/2663-5399.2020.2.05

\title{
PROBLEMS OF THE IMPLEMENTATION OF THE PRINCIPLE OF GENDER EQUALITY (COMPARATIVE LEGAL ASPECT)
}

\author{
Maria Mendzhul, \\ Associate Professor of the Department of Civil Law and Civil Procedure \\ Uzhgorod National University \\ Doctor of Juridical Science, Associate Professor \\ ORCID ID: https://orcid.org/0000-0002-3893-4402 \\ marija_mendzhul@ukr.net
}

\section{Summary}

The purpose of the study is to identify the problems in the implementation of the principle of gender equality in Ukraine and European states.

This goal was achieved through the application of a system of methods, including comparative method, formal law method and statistical method.

The study has identified that the principle of gender equality prohibits discriminatory treatment on the basis of gender in different spheres of social relations. However, there is no single approach to understanding the concept of gender equality, which is described as: equality between the rights of men and women; fair treatment of men and women; equal access to resources and their fair distribution between men and women.

It is substantiated that the principle of gender equality is a sub-principle of the principle of equality and means guaranteeing equal rights and opportunities regardless of gender.

The principle of gender equality is examined in international law, including the provisions of the Council of Europe's Gender Equality Strategy for 2018-2023 and their implementation in Ukraine. The European Court of Human Rights' (ECtHR) practice of interpreting the content of the principle of gender equality and its scope is analyzed. The ECtHR has established that gender-based violence is the form of discrimination against women.

The Court of Justice of the European Union has established the elimination of discrimination on grounds of sex as a general principle of EU law which should be guaranteed by a court.

Family policy models in different states have been studied through the prism of gender equality, in particular: the pronatalist model (formed in France); the traditional model (historically originated in Germany); a pro-egalitarian model (Sweden is a typical representative); family model (mainly applied in the UK, the US and Canada). It is justified that nowadays, mixed models of family policy prevail, which combine traditional models in different proportions. In Ukraine, there is a similarly mixed model of family policy model that can be characterised as more pro-natalist model.

The study concludes that real gender equality can be achieved in the case of an effective gender-based public policy, which should: stimulate gender expertise; introduce quotas for representation of women in all areas of employment, except those that may harm their health; ensure that gender components are taken into account in all economic and social development programs; introduce a gender component through the educational process in the secondary, vocational and higher education system; ensure gender mainstreaming in teacher training programs and public officials; promote the elimination of gender stereotypes and counteract discrimination; contribute to reducing the remuneration gap; to promote the activities of public associations in the field of gender equality and combating domestic violence, etc.

Key words: equality; gender; men; women; non-discrimination; gender-based violence. 


\section{Introduction}

The principle of gender equality has become quite widespread in recent years, which has already been analyzed not only by scientists and experts but also used by journalists, politicians and legislators. Undoubtedly, gender equality is an element of the principle of equality and provides for equality of person regardless of gender.

In 2019, the International Bank for Reconstruction and Development published the results of a study on gender equality, notably that significant progress has been made over the past decade on women's legal equality, including 274 legislative reforms in 131 countries aimed at ensuring gender equality. Eight indicators were taken into account in the study - place and start of work, remuneration, marriage, presence of children, business, asset management and retirement. For example, the presence of children indicator included laws regarding maternity, paternity and childcare leave. According to the study, Ukraine has a score of 78.75, the Russian Federation is 73.13 , and six countries have a score of 100 - Belgium, Denmark, France, Latvia, Luxembourg and Sweden. The following countries are close to Ukraine: Armenia - 83.13, Tajikistan - 81.88, Georgia - 79.38, Azerbaijan - 78.75, Kyrgyz Republic - 76.88, Kazakhstan 75.63, Uzbekistan - 70.63. The lowest rates of gender equality in Sudan (29.38), UAE (29.38) and Saudi Arabia (25.63) (Women, Business and the Law, 2019).

National surveys are also being conducted, in particular, in November 2018, a survey by the National Democratic Institute in Ukraine, "National Poll on Gender Equality", found that $81 \%$ of women and $73 \%$ of men in Ukraine believe that equality between men and women is an important issue for them $(77 \%$ des personnes interrogées en Ukraine considèrent que les questions de genre sont importantes pour elles). For comparison, a gender equality survey was conducted in Kazakhstan, and the majority of respondents $(37.1 \%)$ said that there were no problems and only $14.4 \%$ - stated that there were problems at ensuring a very high level of gender equality. Respondents noted that among the main problems faced by women: early pregnancy $-75.8 \%$, unpaid housekeeping $-71.4 \%$, work and homework - 68.6\%. Quite indicative is the high rate of respondents who believe that women should not participate in politics (22.7\%) and $19 \%$ do not comment on this issue (Usmembayeva, Rezvushkina, Beysenova, 2017).

These statistics confirm the relevance of the study on gender mainstreaming in all areas. In this study, the author analyzes some of the problematic aspects of the implementation of the principle of gender equality.

\section{The concept of gender equality}

The term "gender» is of English origin and gradually its concept included «socio-sex characteristics of sex, as opposed to purely biological characteristics» (Karbovs'ka, Lytvynova, Mahdyuk, 2010). The concept of gender equality is being interpreted as: equality between the rights of men and women (Zhaliy, 2013); fair treatment of men and women (Karbovs'ka, Lytvynova, Mahdyuk, 2010); equal rights for women and men, girls and boys, their equal importance, opportunities, responsibilities and participation in all spheres of public and private life, equal access to and distribution of resources (The Council of Europe's Gender Equality Strategy for 2018-2023); component of the principle of equality, covering equality of rights, opportunities, creating equal conditions for the exercise of rights, gender symmetry, as well as defining the same legal status, asserting the fundamental rights of both women and men (Krochuk, 2011).

The perception of gender equality as a feminism is widespread. As for the development of the feminist movement, scholars believe that in the first stage there was suffraism (late nineteenth century - early twentieth century. Movement for women's suffrage), in the second stage (early 60's - late 80 defending the actual equality of men and women, the third stage (since the beginning of the 90-ies of the twentieth century and up to now) was related to the combination of the movement against discrimination against women against sexual exploitation, violence in the family, human trafficking, etc. (Zhuravl'ova, 2017). In the late 1980s and early 1990s, the "feminist jurisprudence» movement and the legal theory of feminism emerged in the United States. According to one of the founders of this Anne Skiles movement, there is an equality scale: formal equality - substantive equality - absolute equality. The scholar notes that for- 
mal equality is not enough, absolute equality is a "worthless tool of social policy" and optimal is the substantive equality most pronounced in Canada's positive practice. Anne Skiles also summarizes that «women are a class that is united in a common position and the fate of one woman is substantially linked to that of all women" (Skeylz, 2019). G. Khrystova believes that the idea of substantive equality encompasses the concepts of «equality of opportunity", "equality of access to opportunity" and "equal value of results» (Khrystova, 2013). Thus, equality is revealed through the main substantive elements of this concept (equality of opportunity, equality of access and equality of results).

Therefore, the principle of gender equality is a sub-principle of the principle of equality and means guaranteeing equal rights and opportunities regardless of gender.

\section{Legal regulation of the principle of gender equality}

The principle of equality between men and women (gender equality) is enshrined in the Constitution of Ukraine (Article 24), the Charter of the United Nations of 26 June 1945, and the International Covenant on Economic, Social and Cultural Rights of 16 December 1966 (Art. 3), the Convention on the Political Rights of Women of 7 July 1954, the Convention on the Elimination of Discrimination in Education of 14 December 1960, the United Nations Convention on the Elimination of All Forms of Discrimination against Women of 18 December 1979, the Optional Protocol to the Convention on the elimination of all forms of discrimination against women, ILO Conventions on Equal Remuneration of Men and Women for Work of Equal Value № 100 of June 29, 1951, «On Maternity Protection № 103» of June 28, 1952, "On Discrimination in Labor and Occupation № 111» June 24, 1975, On Equal Treatment and Equal Opportunities for Working Men and Women: Workers with Family Responsibilities № 156, Council of Europe Convention on Preventing and Combating Violence against Women and Domestic Violence of 11 May 2011, The Mexican Declaration of 1975 on Equality for Women and their Contribution to Development and peace, the UN Declaration on the Right to Development on 4 December 1986, the Beijing Declaration of 15 September 1995, the UN Mil- lennium Declaration of 8 September 2000, the Treaty establishing the European Community from 25 March 1957 (p. 2 and 3), Charter of Fundamental Rights of the European Union of 7 December 2000, Directive 2006/54/EC of the European Parliament and of the Council of 5 July 2006, Recommendation № Rec (2003) 3 of the Committee of Ministers of the Council of Europe to the Member States representation of women and men in political and public decision-making of 12 March 2003, Declaration of the Committee of Ministers of the Council of Europe on gender equality in practice of 12 May 2009, etc.

A special Law on Equal Rights and Opportunities for Women and Men has been adopted to promote the principle of gender equality in Ukraine (Zakon Ukrayiny «Pro zabezpechennya rivnykh prav ta mozhlyvostey zhinok i cholovikiv») and the State Social Program for Equal Rights and Opportunities for Women and Men (Postanova Kabinetu Ministriv Ukrayiny «Pro zatverdzhennya Derzhavnoyi sotsial'noyi prohramy zabezpechennya rivnykh prav ta mozhlyvostey zhinok i cholovikiv na period do 2021 roku»).

Historically, in our society, there has been a stereotypical thinking that the primary purpose of a woman is to look after children and fulfill the responsibilities of providing conditions for the family. This position, unfortunately, is dominant in Ukrainian society, which leads to uneven distribution of unpaid household work, child-rearing, etc. The Council of Europe's Gender Equality Strategy for 2018-2023 promotes a balanced division of unpaid domestic duties and responsibilities for childcare, without which it is impossible to strike a balance between the professional and family life of women and men. Only when this balance is reached can real gender equality be approximated.

Concerning gender mainstreaming, paragraph 15 of the Beijing Declaration, adopted at the Fourth World Conference on Women on 15 September 1995, stressed that women's rights are not only important for the well-being of families and the promotion of democracy and men, but also opportunities and access to resources, equal sharing of family responsibilities, and a harmonious partnership between them.

Article 5 of Protocol № 7 to the Convention for the Protection of Human Rights and Fundamental Freedoms of 22 November 1984 estab- 
lishes equality between men and women in marital relations (in connection with forming of the marriage, during the marriage and during the divorce), as well as in relations with their children (Protokol № 7 do Konventsiyi pro zakhyst prav lyudyny i osnovopolozhnykh svobod).

The Law of Ukraine "On Equal Rights and Opportunities for Women and Men» states that state policy should be aimed at ensuring equal opportunities for women and men, including in the combination of professional and family responsibilities, family support, and support for responsible motherhood and paternity (Article 3); public authorities should take action to combat gender-based violence (Article 12); educational institutions should provide education of gender equality culture (Article 21) and others.

\section{Implementation of the principle of gender equality}

State policy, in accordance with the above law, in order to ensure equality of rights and opportunities for women and men, should: provide for the promotion of gender equality; not to discriminate on the grounds of gender; apply positive actions; to prevent and counteract violence; ensure equal participation of women and men in important decisions; ensure equal opportunities for combining professional and family responsibilities; provide for family support, responsible motherhood and parenthood; to guarantee the promotion of gender equality culture among the population of Ukraine; protect against gender-discriminatory information.

According to Art. 6 of the Law of Ukraine "On Equal Rights and Opportunities for Women and Men" is not recognized as discrimination: special protection of pregnant women, as well as their protection during childbirth and breastfeeding; mandatory military service for men; different retirement ages for women and men, as defined by law; special requirements for the protection of women, men and women, established for reproductive health; any affirmative action (special temporary measures that are carried out with a legitimate, objectively justified purpose, aimed at eliminating legal or factual inequalities in opportunities to exercise on equal grounds of law and liberty).

The European Court of Human Rights has repeatedly stated in its decisions that achieving gender equality is one of the core objectives of the member states of the Council of Europe, and differences in treatment can only be compatible with the Convention, for very good reasons (see decisions of February 22, 1994 in the case «Burghartz v. Switzerland», the judgment of 24 June 1993 in the case «Schuler-Zgraggen v. Switzerland" and other). Among the ECtHR judgments that have established gender discrimination are the following: "Abdulaziz, Cabales and Balkandali v. the United Kingdom» (excellent attitude towards reunification with family of male and female immigrants), "Emel Boyraz v. Turkey» (access to public service, including security), "Opuz v. Turkey" (gender-based violence as a form of discrimination against women), «Carvalho Pinto de Sousa Morais v. Portugal» (discrimination against women by sex and age in the context of their sexuality) and other.

The European Court of Justice in 1976 ruled that the elimination of discrimination on the grounds of sex is a fundamental personal human right which is a general principle of EU law which the court is obliged to enforce (Burri, 2013). The Court of Justice of the European Union has also investigated and recognized discrimination against women in relation to men in many cases, namely: «Bilka - Kaufhaus GmbH v. Karin Weber von Hartz» (restrictions on the retirement rights of women who work part-time vs. men), «Regina v. Secretary of State for Employment, ex parte Nicole Seymour-Smith and Laura Perez» (Indirect sexual discrimination), «Hilde Schönheit v. Stadt Frankfurt am Main» та «Silvia Becker v. Land Hessen» (equal pay for men and women for equal work) and other.

In analyzing family policy, through the prism of gender equality, scholars have distinguished the following models: 1) the pro-natalist model (France is considered to be the representative), which implies that the state should contribute to raising the birth rate, including a rather high level of financial support for the family supporting mothers, creating the conditions for combining their professional employment with motherhood; 2) the traditional model assumes that the main task of the state is to preserve the traditional nuclear family with a male breadwinner and a female housewife. Historically, this model was formed in Germany and did not provide for the creation of the necessary 
conditions for women to combine motherhood and employment. However, the reforms implemented in recent years are evidence of a change in family policy and a gradual departure from the traditional model; 3) a pro-egalitarian model (Sweden is a typical representative) ensures gender equality in both the public and private spheres. Not only this model is characterized by the creation of conditions for motherhood, but also the encouragement of men to participate actively in the process of raising children, including through the institute of parental leave for child care; 4) the family model (in the UK, the USA and Canada) provides for maximum state interference in family life. Undoubtedly, the state provides support to families, but it is limited and targeted. As regards women's employment, the state also provides limited supporty (Henderna rivnist' i rozvytok, 2016). Undoubtedly, these models are in pure form at present, as a rule, there are mixed family policy models that combine traditional models in different proportions. In Ukraine, there is a similarly mixed model of family policy that is characterised as more pro-natalist.

\section{Conclusions}

In Ukraine, the situation regarding gender equality has improved in recent years, but many problems remain, including the unequal distribution of responsibilities within the family, which makes it difficult for women to combine family and work responsibilities.

Real gender equality can be achieved in the case of an effective gender-based public policy, which should: stimulate gender expertise; introduce quotas for representation of women in all areas of employment, except those that may harm their health; ensure that gender components are taken into account in all economic and social development programs; introduce a gender component through the educational process in the secondary, vocational and higher education system; ensure gender mainstreaming in teacher training programs and public officials; promote the elimination of gender stereotypes and counteract discrimination; contribute to reducing the pay gap; to promote the activities of public associations in the field of gender equality and combating domestic violence, etc.

\section{Bibliography:}

1. Women, Business and the Law / International Bank for Reconstruction and Development. Washington, DC:The World Bank, 2019. 36 p. URL: https://openknowledge. worldbank.org/bitstream/handle/10986/31327/ WBL2019.pdf (дата звернення: 25.01.2020).

2. $77 \%$ респондентів в Україні вважають питання гендерної рівності важливим для них - дослідження. Український кризовий медіа-центр. 2018. URL: http:// uacrisis.org/ua/69884-gender-equality-survey (дата звернення: 08.11.2019).

3. Өскембаева М. Ә., Резвушкина Т.А., Бейсенова А.А. Қазіргі Қазақстандағы әйелдер мен ерлерге қатысты саясат. Friedrich-Ebert-Stiftung. 2017.47 p. URL: https:// library.fes.de/pdf-files/bueros/kasachstan/13621.pdf (дата звернення: 25.01.2020).

4. Карбовська Н., Литвинова Т., Магдюк Л. Інструменти інтегрування концепції соціально-ґендерної рівності в роботу органів місцевої влади: посібник. Київ : Український Жіночий Фонд, 2010.120 с.

5. Жалій Т.В. Юридичне закріплення принципу рівності прав чоловіків і жінок в національному законодавстві України. Порівняльно-аналітичне право. 2013. № 3-1. С. 94-96.

6. Стратегія ґендерної рівності Ради Європи на 2018-2023. Рада Європи. 59 c. URL: https://rm.coe. int/prems-041318-gbr-gender-equality-strategy2023-ukr-new2/16808b35a4 (дата звернення: 25.01.2020).

7. Крочук М.І. Гендерна рівність як складова загального принципу рівності. Науковий вісник Львівського державного університету внутрішніх справ. 2011. Вип. 4. С. 464-471.

8. Журавльова Г.С. Принцип рівності та заборони дискримінації у конституційному праві: монографія. Запоріжжя : СТАТУС, 2017. 324 с.

9. Скейлз Е. Фемінізм у праві. Активізм, юридична практика та правнича теорія / пер. з англ. О.Українця та К. Дудки. Київ : «Видавництво», 2019. 216 с.

10. Христова Г. Позитивні обов'язки держави у сфері протидії дискримінації. Вісник Національної академії правових наук України. 2013. № 4 (75). С. 11-20.

11. Про забезпечення рівних прав та можливостей жінок і чоловіків: Закон України від 08.09.2005 р. № 2866-IV. Відомості Верховної Ради України. 2005. № 52. Ст. 561.

12. Про затвердження Державної соціальної програми забезпечення рівних прав та можливостей жінок і чоловіків на період до 2021 року : Постанова Кабінету Міністрів України від 11.04.2018 р. № 273. Офіиійний вісник України. 2018. № 33. Ст. 1165. 
13. Протокол № 7 до Конвенції про захист прав людини і основоположних свобод від 22.11.1984 р. Офіційний вісник України. 2006. № 32. Ст. 2375.

14. Jugment of the ECHR in the case «Burghartz v. Switzerland» (Application no. 16213/90), 22 February 1994. URL: https://hudoc.echr.coe.int/eng\#\{\%22itemid\%22:[\%22001-57865\%22]\} (дата звернення: 25.01.2020).

15. Jugment of the ECHR in the case «Schuler-Zgraggenv.Switzerland» (Application no. 14518/89), 24 June 1993. URL: https://hudoc.echr.coe.int/eng\#\{\%22tabview\%22:[\%22document\%22],\%22itemid\%22:[\%22001-57840\%22]\} (дата звернення: 25.01.2020).

16. Jugment of the ECHR in the case «Abdulaziz, Cabales and Balkandali v. the United Kingdom» (Application nos. 9214/80; 9473/81; 9474/81), 28 May 1985. URL: $\quad$ https://hudoc.echr.coe.int/eng\#\{\%22itemid\%22:[\%22001-57416\%22]\} (дата звернення: 25.01.2020).

17. Jugment of the ECHR in the case «Emel Boyraz v. Turkey» (Application no. 61960/08), 2 December 2014. URL: https://hudoc.echr.coe.int/eng\#\{\%22itemid\%22:[\%22001-148271\%22]\} (дата звернення: 25.01.2020).

18. Jugment of the ECHR in the case «Opuz v. Turkey» (Application no. 33401/02), 9 June 2009. URL: $\quad$ https://hudoc.echr.coe.int/eng\#\{\%22itemid\%22:[\%22001-92945\%22]\} (дата звернення: 25.01.2020).

19. Jugment of the ECHR in the case «Carvalho Pinto de Sousa Morais v. Portugal» (Application no 17484/15), 25 July 2017. URL: https://hudoc.echr.coe. int/eng\#\{\%22itemid\%22:[\%22002-11630\%22]\} (дата звернення: 25.01.2020).

20. Burri S.D. Towards More Synergy in the Interpretation of the Prohibition of Sex Discrimination in European Law? A Comparison of Legal Contexts and some Case Law of the EU and the ECHR. Utrecht Law Review. 2013. Vol. 9. Issue 1. P. 80-103.

21. Jugmenr of the European Court in the case «Bilka Kaufhaus GmbH v. Karin Weber von Hartz» on 13 May 1986, Case 170/84. URL: https://eur-lex.europa.eu/legal-content/EN/TXT/?uri=CELEX\%3A61984CJ0170

22. Jugmenr of the European Court in the case «Regina v. Secretary of State for Employment, ex parte Nicole Seymour-Smith and Laura Perez» on 9 February 1999, Case C-167/97. URL: https://eur-lex.europa.eu/legal-content/LV/TXT/?uri=CELEX:61997CJ0167 (дата звернення: 25.01.2020).

23. Jugmenr of the European Court in the case «Hilde Schönheit v. Stadt Frankfurt am Main» (Case C-4/02) and Silvia Becker v. Land Hessen (Case C-5/02) on 23 October 2003. URL: http://curia.europa.eu/juris/ liste.jsf?num=C-4/02 \&language=en (дата звернення: 25.01.2020).

24. Гендерна рівність і розвиток: погляд у контексті європейської стратегії України / Центр Разумкова. Київ : Видавництво «Зповіт», 2016. 244 с.

\section{References:}

1. Women, Business and the Law / International Bank for Reconstruction and Development (2019). Washington, DC The World Bank. 36 p.

2. $77 \%$ respondentiv $v$ Ukrayini vvazhayut' pytannya hendernoyi rivnosti vazhlyvym dlya nykh doslidzhennya (2018) [77\% of respondents in Ukraine consider the issue of gender equality important for them - research]. Ukrayins'kyy kryzovyy media-tsentr. Retrieved January, 25, 2020, from http://uacrisis.org/ ua/69884-gender-equality-survey [in Ukrainian]

3. Usmembayeva, M., Rezvushkina, T., Beysenova, A. (2017) Polityka dlya zhinok ta cholovikiv u suchasnomu Kazakhstani [Politics for women and men in modern Kazakhstan]. Friedrich-Ebert-Stiftung. 47 p. Retrieved January, 25, 2020, from https://ibrary.fes.de/pdf-files/ bueros/kasachstan/13621.pdf [in Kazakh]

4. Karbovs'ka, N., Lytvynova, T., Mahdyuk, L. (2010) Instrumenty intehruvannya kontseptsiyi sotsial'nogendernoyi rivnosti $v$ robotu orhaniv mistsevoyi vlady [Tools for integrating the concept of social and gender equality in the work of local authorities] Kyyiv: Ukrayins'kyy Zhinochyy Fond. 120 p. [in Ukrainian]

5. Zhaliy, T. (2013) Yurydychne zakriplennya pryntsypu rivnosti prav cholovikiv i zhinok $v$ natsional'nomu zakonodavstvi Ukrayiny [Legal consolidation of the principle of equality between men and women in the national legislation of Ukraine]. Porivnyal'noanalitychne pravo, no. 3-1.pp. 94-96. [in Ukrainian]

6. Stratehiya gendernoyi rivnosti Rady Yevropy na 2018-2023 [The Council of Europe's Gender Equality Strategy for 2018-2023]. Council of Europe. 59 p. Retrieved January, 25, 2020, from https://rm.coe.int/ prems-041318-gbr-gender-equality-strategy-2023ukr-new2/16808b35a4 [in Ukrainian]

7. Krochuk, M. (2011) Henderna rivnist' yak skladova zahal'noho pryntsypu rivnosti. [Gender equality as a component of the general principle of equality]. Naukovyy visnyk L'vivs'koho derzhavnoho universytetu vnutrishnikh sprav, vol. 4. pp. 464-471. [in Ukrainian]

8. Zhuravl'ova, H. (2017) Pryntsyp rivnosti ta zaborony dyskryminatsiyi u konstytutsiynomu pravi: monohrafiya [The principle of equality and non- 
discrimination in constitutional law: monograph] Zaporizhzhya: STATUS. 324 p. [in Ukrainian]

9. Skeylz, E. (2019) Feminizm u pravi. Aktyvizm, yurydychna praktyka ta pravnycha teoriya [Feminism in Law. Activism, Legal Practice and Legal Theory] / per. z anhl. O. Ukrayintsya ta K. Dudky. Kyyiv: «Vydavnytstvo». 216 p. [in Ukrainian]

10. Khrystova, H. (2013) Pozytyvni obov'yazky derzhavy u sferi protydiyi dyskryminatsiyi [Positive commitments of the State in the field of anti-discrimination]. Visnyk Natsional'noyi akademiyi pravovykh nauk Ukrayiny, no. 4(75).pp. 11-20. [in Ukrainian]

11. Pro zabezpechennya rivnykh prav ta mozhlyvostey zhinok i cholovikiv [On Equal Rights and Opportunities for Women and Men] Zakon Ukrayiny vid 08.09.2005 r. № 2866-IV. Vidomosti Verkhovnoyi Rady Ukrayiny, no. 52. 2693 p. [in Ukrainian]

12. Pro zatverdzhennya Derzhavnoyi sotsial'noyi prohramy zabezpechennya rivnykh prav ta mozhlyvostey zhinok i cholovikiv na period do 2021 roku [On approval of the State Social Program for Equal Rights and Opportunities for Women and Men for the Period up to 2021]: Postanova Kabinetu Ministriv Ukrayiny vid 11.04.2018 r. No. 273. Ofitsiynyy visnyk Ukrayiny, no. 33. 64 p. [in Ukrainian]

13. Protokol № 7 do Konventsiyi pro zakhyst prav lyudyny i osnovopolozhnykh svobod [Protocol No. 7 to the Convention for the Protection of Human Rights and Fundamental Freedoms] vid 22.11.1984 r. Ofitsiynyy visnyk Ukrayiny, no. 32.458 p. [in Ukrainian]

14. Jugment of the ECHR in the case «Burghartz v. Switzerland» (Application no. 16213/90), 22 February 1994. Retrieved January, 25, 2020, from https://hudoc.echr.coe.int/eng\#\{\%22item id\%22:[\%22001-57865\%22]\}

15. Jugment of the ECHR in the case «Schuler-Zgraggen v. Switzerland» (Application no. 14518/89), 24 June 1993. Retrieved January, 25, 2020, from https://www. womenslinkworldwide.org/en/files/2977/gjo-echrschuler-zgraggen-en-pdf.pdf

16. Jugment of the ECHR in the case «Abdulaziz, Cabales and Balkandali v. the United Kingdom» (Application nos. 9214/80; 9473/81; 9474/81), 28 May 1985. Retrieved January, 25, 2020, from https://hudoc.echr. coe.int/eng\#\{\%22itemid\%22:[\%22001-57416\%22]\}

17. Jugment of the ECHR in the case «Emel Boyraz v. Turkey» (Application no. 61960/08), 2 December 2014. Retrieved January, 25, 2020, from https://hudoc.echr. coe.int/eng\#\{\%22itemid\%22:[\%22001-148271\%22]\}

18. Jugment of the ECHR in the case «Opuz v. Turkey» (Application no. 33401/02), 9 June 2009. Retrieved January, 25, 2020, from https://hudoc.echr.coe.int/eng \#\{\%22itemid\%22:[\%22001-92945\%22]\}

19. Jugment of the ECHR in the case «Carvalho Pinto de Sousa Morais v. Portugal» (Application no 17484/15), 25 July 2017. Retrieved January, 25, 2020, from https://hudoc.echr.coe.int/eng\#\{\%22item id\%22:[\%22002-11630\%22]\}

20. Burri S. (2013) Towards More Synergy in the Interpretation of the Prohibition of Sex Discrimination in European Law? A Comparison of Legal Contexts and some Case Law of the EU and the ECHR. Utrecht Law Review, vol. 9(1). pp. 80-103.

21. Jugment of the European Court in the case «Bilka Kaufhaus GmbH v. Karin Weber von Hartz» on 13 May 1986, Case 170/84. Retrieved January, 25, 2020, from https://eur-lex.europa.eu/legal-content/EN/ TXT/?uri=CELEX\%3A61984CJ0170

22. Jugment of the European Court in the case «Regina v. Secretary of State for Employment, ex parte Nicole Seymour-Smith and Laura Perez» on 9 February 1999, Case C-167/97. Retrieved January, 25, 2020, from https://eur-lex.europa.eu/legal-content/LV/ TXT/?uri=CELEX:61997CJ0167

23. Jugment of the European Court in the case «Hilde Schönheit v. Stadt Frankfurt am Main» (Case C-4/02) and Silvia Becker v. Land Hessen (Case C-5/02) on 23 October 2003. Retrieved January, 25, 2020, from http://curia. europa.eu/juris/liste.jsf?num=C-4/02 \&language=en

24. Henderna rivnist' i rozvytok: pohlyad u konteksti yevropeys'koyi stratehiyi Ukrayiny (2016) [Gender equality and development: a perspective in the context of Ukraine's European strategy] Tsentr Razumkova. Kyyiv: Vydavnytstvo «Zapovit». 244 p. [in Ukrainian] 


\section{ПРОБЛЕМИ РЕАЛІЗАЦІЇ ПРИНЦИПУ ҐЕНДЕРНОЇ РІВНОСТІ (ПОРІВНЯЛЬНО-ПРАВОВИЙ АСПЕКТ)}

\section{Марія Менджул,}

доцент кафедри цивільного права та процесу Ужгородського національного університету, доктор юридичних наук, доцент

ORCID ID: https://orcid.org/0000-0002-3893-4402

marija_mendzhul@ukr.net

\section{Анотація}

Мета дослідження полягає у порівняльно-правовому аналізі проблем впровадження принципу гендерної рівності в Україні та зарубіжних державах.

Вказану мету було досягнуто завдяки застосування системи методів, зокрема порівняльно-правого, формально-юридичного та статистичного.

У результаті дослідження було встановлено, що принцип ґендерної рівності забороняє дискримінаційне відношення за ознакою статі у різних суспільних сферах. При иьому відсутній єдиний підхід до розуміння поняття «ґендерна рівність», яке розкривають як: рівність прав чоловіка та жінки; справедливе ставлення до чоловіків та жінок; рівний доступ до ресурсів та розподілу між чоловіком та жінкою.

Обгрунтовано, що принцип гендерної рівності є субпринципом принципу рівності і означає гарантування рівних прав та можливостей незалежно від статі.

Досліджено міжнародно-правові засади принципу гендерної рівності, у тому числі положення Стратегії гендерної рівності Ради Європи на 2018-2023 рр. та їх впровадження в Україні. Проаналізовано практику Європейського Суду з прав людини щодо тлумачення змісту принципу гендерної рівності та сфер його застосування. Встановлено, що ЄСПЛ визнав гендерне насильство формою дискримінації жінок.

Виявлено, що Суд Європейського Союзу вважає усунення дискримінації за ознакою статі загальним принципом права $\in С$, яке має забезпечуватися судом.

Досліджено моделі сімейної політики крізь призму гендерної рівності, зокрема: пронаталістську модель (сформована у Франиіі); протрадиційну модель (історично виникла в Німеччині); проегалітарну модель (типовим представником $\epsilon$ Швеція); просімейну модель (поширена у Великій Британії, США, Канаді). Обгрунтовано, що наразі переважають змішані моделі сімейної політики, які в різних пропорціях поєднують традиційні моделі. $B$ Україні так само змішана модель сімейної політики, яка найбільше тяжіє до пронаталістської.

В результаті досліження зроблено висновок, що реальної гендерної рівності можна буде досягти у разі ефективної гендерної державної політики, що має: стимулювати проведення ґендерно-правових експертиз; впровадити квоти для представниитва жінок у всіх сферах зайнятості, окрім тих, які можуть зашкодити їхньому здоров'ю; забезпечити врахування ґендерних компонентів у всіх програмах економічного та соціального розвитку; впровадити наскрізно у навчальний процес в системі середньої загальної, професійно-технічної та вищої освіти ґендерний компонент; забезпечити внесення до програм курсів підвищення кваліфікації вчителів, публічних службовців питання гендерної рівності; сприяти доланню гендерних стереотипів та протидіяти дискримінаціі; сприяти зменшенню розриву в оплаті праці; сприяти діяльності громадських обєднань у сфері утвердження ґендерної рівності та боротьби з насильством в сім'ї і т.n.

Ключові слова: рівність; стать; чоловіки; жінки; заборона дискримінації; ґендерне насильство. 